\title{
Burden of disability in a post war birth cohort in the UK
}

\author{
D J L Kuh, M E J Wadsworth, E J Yusuf
}

\begin{abstract}
Study objective - To report the prevalence of physical disability in a national sample of 43 year old men and women, and examine the relationship between disability and the consumption of hospital care. To assess the contribution of childhood health and social circumstances to the risk of adult disability, and the socioeconomic consequences of disability.
\end{abstract}

Design - The assessment of disabilities of physical movement was based on criteria developed by OPCS for their national survey of disability. The analysis used data on socioeconomic circumstances from childhood to 43 years and on serious illness in the first 25 years of life collected prospectively on members of the MRC National Survey of Health and Development, the 1946 birth cohort study. Setting - England, Wales, and Scotland. Participants - A general population sample of 3235 men and women aged 43 years.

Main results - Seven per cent of cohort survivors at 43 years were physically disabled and a further $3 \%$ reported difficulties although they were not assessed as disabled according to OPCS criteria. The prevalence of severe disability at this age was similar to that derived from the OPCS survey but the prevalence of mild disability was substantially greater. Disability was associated with a greater use of hospital care in recent years and throughout life. Those who had experienced a serious illness in earlier life were over twice as likely to be disabled; certain conditions, such as polio, were associated with a particularly high relative risk. Those who had had a socially disadvantaged start to life were more likely to be physically disabled at 43 years but the strength of this relationship was considerably weakened by adjustment for later social factors, suggesting that social disadvantage throughout life, or during adult life, increased the risk of disability. Taking these results into account the relative impact of disability on income and employment was found to be greatest for those from the unskilled and semiskilled classes.

Conclusions - The prevalence of physical disability among those in early middle age may be greater than previously estimated. The strong links between childhood ill health and adult disability and its association with high levels of hospital care support longstanding recommendations for better coordination between child and adult health services. Social disadvantage affects the risk of disability and its financial and employment consequences.

(f Epidemiol Community Health 1994;48:262-269)

As life expectancy rises an increasingly important aspect of population health is the level of disability resulting from bodily impairments which are themselves products of disease, injury, or the intrinsic ageing process. Disability refers to "any restriction or lack (resulting from an impairment) of ability to perform an activity in the manner or within the range considered normal for a human being". Interest in disability is growing as findings from Britain and the United States suggest that over the past decade there has been a significantly slower growth (if any) in disability free life expectancy than in life expectancy itself. ${ }^{2-4}$ There is a need for greater understanding of the extent of disability, its risk factors, and the health care and social consequences of disability so that health and social policies for prevention, and for improving the quality of life after the onset of disability, can be developed.

Findings from a detailed national survey of 10000 disabled adults in this country carried out by the Office of Population Censuses and Surveys (OPCS) showed that disability was strongly associated with age, socioeconomic disadvantage, and with increased consumption of health care. ${ }^{5-6}$ According to this cross sectional survey the rate of increase in disability begins to accelerate in early middle age.

The Medical Research Council's National Survey of Health and Development (NSHD), a national prospective cohort of men and women followed up since their births in March 1946 , so far until the age of 43 years, collected information on disability at the last visit which is comparable to information from the OPCS survey. The first part of this paper reports the prevalence of disabilities of physical movement in this nationally representative sample of 43 year olds and examines the relationship between disability and the consumption of hospital care.

Cross sectional surveys commonly find that disabled people are less educated, have lower incomes, and are more likely to have manual occupations or be out of work. ${ }^{6-10}$ Longitudinal studies are needed to examine whether socioeconomic factors are risk factors for or consequences of adult disability, or both. Several 
longitudinal studies of heart disease have investigated long term predictors of disability, ${ }^{11-13}$ but their interest has been in identifying particular cardiovascular risk factors in adult life which predict disability in old age.

The NSHD has prospective data on health and socioeconomic factors from childhood and is uniquely placed to assess their contribution to the risk of disability in adult life and to examine the socioeconomic consequences of disability, after allowing for a possible selection effect. The paper addresses three specific questions. Firstly, did those who survived serious illness in this cohort in their earlier lives experience a greater risk of disability in adult life? Secondly, is there a relationship between childhood socioeconomic circumstances and adult disability and, if so, is this explained either by the experience of serious illness in earlier life or because those from poor family backgrounds were more likely to experience poor adult circumstances? Thirdly, is the drop in the standard of living resulting from disability cushioned for those who had previously attained a relatively high standard of living?

\section{Methods}

The NSHD is a socially stratified sample of 5362 single, legitimate males and females born in the first week of March 1946 and followed up ever since. Information has been collected on medical, psychological, educational, and social matters, at least every two years in childhood and at about five yearly intervals in adult life. At age 43 years, research nurses successfully interviewed and measured 3262 cohort members in their homes, $85 \%$ of the interviews attempted. This represents $61 \%$ of the original cohort; of the remainder $7 \%$ had already died, $11 \%$ were living abroad, $10 \%$ had previously refused to participate in the study, and $11 \%$ were not interviewed for other reasons at age 43 years. Loss from death and emigration have occurred at population appropriate rates and the sample remains representative of the population born in Britain at that time. ${ }^{14}$ Prevalence figures given in the results section have been reweighted to allow for the original sample stratification.

\section{ASSESSMENT OF PHYSICAL DISABILITY AT 43}

YEARS

The assessment of physical disability used the same criteria as that used in the OPCS disability survey. ${ }^{5}$

At a home interview at age 43 years, cohort members completed a screening questionnaire indicating whether, because of physical or mental ill health, they had difficulty with certain locomotor activities (walking for a quarter of a mile on the level, going up or down steps or stairs, bending down and straightening up without holding on to anything, falling or keeping balance), using arms to reach or stretch for things, using hands to hold, grip or turn things, and carrying out a number of personal self care activities. These questions were based on the OPCS postal questionnaire designed to screen in people at a lower level of severity than required in order not to exclude anybody.

Trained research nurse interviewers administered a questionnaire to those who reported any difficulties which asked about their ability to perform specific tasks (such as picking up and carrying a pint of milk or tucking in a shirt at the back). These tasks matched those asked about in the OPCS survey and OPCS criteria were used to ascertain whether the threshold level had been reached in four areas of disability (locomotion, reaching and stretching, dexterity, and personal self care) and to assess the severity of each disability. In the OPCS study those people identified at the screening stage as having difficulties, who were subsequently interviewed and did not reach the threshold level for disability, were excluded from the survey. In this cohort study such people were classified into a separate group, and distinguished from those with a disability and those who reported no difficulties.

The OPCS Common Severity Scales for type of disability had been derived from the assessments of people with disabilities and those who cared for them, professionals with expertise in disability, and workers from voluntary organisations concerned with disability. The scales had between 6 and 13 levels and the scores for each level ranged between 0.5 and 11.5 . Full details of the scales have been published by OPCS. ${ }^{5}$ For this paper, because of the small numbers involved, each scale was collapsed into two categories, the severe category containing half the levels (those with the highest scores) and the mild category containing the others.

The sample comprises 3235 cohort members, $97 \%$ of all those interviewed at age 43 years. Of the 27 who did not complete the disability self completion form, four were already known to be mentally handicapped. For those unable to complete the questionnaire, interviewers collected the information from the nearest carer but this was not possible in these four cases. As the analyses showed that those with a history of mental handicap were more likely than their peers to be limited in their physical movement the prevalence figures may be very slightly underestimated.

\section{EARLIER EXPERIENCE OF SERIOUS ILLNESS}

Serious illness in infancy ( $0-4$ years), childhood (5-14 years), and adolescence and early adulthood (15-24 years) was defined as any condition which necessitated hospital admission for a minimum of 28 days or school or work absence of three consecutive weeks ${ }^{15}$ and was coded according to the International Classification of Diseases (9th revision). ${ }^{16}$

\section{MEASUREMENT OF LIFETIME SOCIOECONOMIC} CIRCUMSTANCES

Childhood socioeconomic circumstances were assessed by parental education, social class, domestic crowding, and household amenities. The measure of parental education (collected 
Table 1 Population prevalence of physical disability (rate per 1000) in the NSHD and the OPCS survey. Those in provate households only

\begin{tabular}{|c|c|c|c|c|c|c|c|}
\hline & \multirow{2}{*}{$\begin{array}{l}\text { OPCS } \\
\text { severity } \\
\text { score }\end{array}$} & \multicolumn{3}{|l|}{ Men } & \multicolumn{3}{|l|}{ Women } \\
\hline & & $\begin{array}{l}\text { NSHD } \\
43-44 y\end{array}$ & $\begin{array}{l}\text { OPCS } \\
40-44 y\end{array}$ & $45-49 y$ & $\begin{array}{l}\text { NSHD } \\
43-44 y\end{array}$ & $\begin{array}{l}O P C S \\
40-44 y\end{array}$ & $45-49 y$ \\
\hline \multicolumn{8}{|l|}{ Locomotion: } \\
\hline $\begin{array}{l}\text { Disability: Severe } \\
\text { Mild } \\
\text { Difficulties only }\end{array}$ & $\begin{array}{l}(\geqslant 5.5) \\
(<5.5) \\
(\mathrm{n} / \mathrm{a})\end{array}$ & $\begin{array}{l}10 \\
31 \\
24\end{array}$ & $\begin{array}{l}10 \\
12 \\
\mathrm{n} / \mathrm{a}\end{array}$ & $\begin{array}{l}14 \\
23 \\
\mathrm{n} / \mathrm{a}\end{array}$ & $\begin{array}{l}16 \\
49 \\
31\end{array}$ & $\begin{array}{l}12 \\
19 \\
\mathrm{n} / \mathrm{a}\end{array}$ & $\begin{array}{l}15 \\
28 \\
\mathrm{n} / \mathrm{a}\end{array}$ \\
\hline \multicolumn{8}{|l|}{ Reaching and stretching: } \\
\hline $\begin{array}{l}\text { Disability: Severe } \\
\text { Mild } \\
\text { Difficulties only }\end{array}$ & $\begin{array}{l}(\geqslant 5.5) \\
(<5.5) \\
(n / a)\end{array}$ & $\begin{array}{r}2 \\
13 \\
12\end{array}$ & $\begin{array}{c}2 \\
4 \\
\mathrm{n} / \mathrm{a}\end{array}$ & $\begin{array}{c}3 \\
6 \\
\mathrm{n} / \mathrm{a}\end{array}$ & $\begin{array}{r}12 \\
17 \\
8\end{array}$ & $\begin{array}{c}3 \\
8 \\
\mathrm{n} / \mathrm{a}\end{array}$ & $\begin{array}{c}6 \\
9 \\
\mathrm{n} / \mathrm{a}\end{array}$ \\
\hline \multicolumn{8}{|l|}{ Dexterity: } \\
\hline $\begin{array}{c}\text { Disability: Severe } \\
\text { Mild } \\
\text { Difficulties only }\end{array}$ & $\begin{array}{l}(\geqslant 5 \cdot 5) \\
(<5 \cdot 5) \\
(\mathrm{n} / \mathrm{a})\end{array}$ & $\begin{array}{r}9 \\
5 \\
15\end{array}$ & $\begin{array}{c}5 \\
1 \\
\mathrm{n} / \mathrm{a}\end{array}$ & $\begin{array}{c}10 \\
2 \\
\mathrm{n} / \mathrm{a}\end{array}$ & $\begin{array}{l}17 \\
12 \\
20\end{array}$ & $\begin{array}{c}15 \\
1 \\
\mathrm{n} / \mathrm{a}\end{array}$ & $\begin{array}{c}20 \\
3 \\
\mathrm{n} / \mathrm{a}\end{array}$ \\
\hline \multicolumn{8}{|l|}{ Personal care: } \\
\hline Disability: Severe & $\begin{array}{l}(\geqslant 4.5) \\
(<4.5)\end{array}$ & $\begin{array}{r}6 \\
12\end{array}$ & $\begin{array}{l}7 \\
6\end{array}$ & $\begin{array}{r}14 \\
7\end{array}$ & $\begin{array}{r}8 \\
20\end{array}$ & $\begin{array}{r}12 \\
7\end{array}$ & $\begin{array}{l}13 \\
12\end{array}$ \\
\hline $\begin{array}{l}\text { Difficulties only } \\
\text { Any severe disability }\end{array}$ & $(\mathrm{n} / \mathrm{a})$ & $\begin{array}{r}4 \\
19\end{array}$ & $\begin{array}{l}\mathrm{n} / \mathrm{a} \\
16\end{array}$ & $\begin{array}{l}\mathrm{n} / \mathrm{a} \\
22\end{array}$ & $\begin{array}{r}3 \\
34\end{array}$ & $\begin{array}{l}\mathrm{n} / \mathrm{a} \\
26\end{array}$ & $\mathrm{n} / \mathrm{a}$ \\
\hline $\begin{array}{l}\text { Any mild disability } \\
\text { (but no severe disability) }\end{array}$ & & 41 & 11 & 19 & 53 & 14 & 21 \\
\hline $\begin{array}{l}\text { Any difficulties } \\
\text { (but no disability) }\end{array}$ & & 30 & $\mathrm{n} / \mathbf{a}$ & $\mathrm{n} / \mathrm{a}$ & 37 & $\mathrm{n} / \mathrm{a}$ & $\mathrm{n} / \mathrm{a}$ \\
\hline
\end{tabular}

$\mathrm{n} / \mathrm{a}=$ not applicable.

from parents when cohort members were children) distinguished those with a secondary school education. Social class was assigned using the father's occupation when the cohort member was 11 years old, ${ }^{17}$ or if this was unknown (539 cases) similar measures at age 16 years or 4 years. Information on domestic crowding was collected at birth and at 2 and at 4 years. Severe overcrowding (more than three people per room at two or more of these ages) or overcrowding (more than one person per room at any age) was distinguished from less crowded circumstances. A measure of household amenities when the cohort member was 2 years old identified those who had lived in homes without one or more of the following: running hot water or sole use of bathroom or kitchen.

Socioeconomic status of the cohort members in early adulthood was assessed by social class and educational qualifications achieved by 26 years. Educational qualifications were classified by the Burnham Scale, ${ }^{18}$ and grouped into no qualifications, up to O-level or equivalent, A-level or equivalent, or degree level. For men, and for women living without a partner, social class was based on current or last occupation. Women living with a partner were assigned a social class on the basis of their partner's occupation.

Socioeconomic status at 43 years was assessed by employment status (distinguishing those in paid work, those currently wanting work, and those not wanting paid work), social class, self reported household net income, housing tenure, and marital status.

\section{METHODS OF ANALYSIS}

Three groups at age 43 years were identified those with physical disabilities according to OPCS criteria, those reporting difficulties but who were not assessed as disabled (who would have been excluded in the OPCS survey), and those who reported no problems with their physical movement. The prevalence of physi- cal disabilities at 43 years, weighted to allow for sample stratification, was compared with the prevalence of these disabilities for similar age groups in the OPCS national survey of disability. The OPCS data set was obtained from the ESRC data archive for this purpose. Significant relationships between physical disability and difficulty at 43 years with recent and lifetime health service use, socioeconomic circumstances at different life stages, and serious illness before 25 years were identified on the basis of $\chi^{2}$ tests. Logistic regression models were used to identify the most powerful predictors of physical disability at 43 years using the BMDP statistical package. ${ }^{19}$ The sex of the survey member was entered as an independent variable as there was a significant difference in the prevalence of disability between men and women.

\section{Results}

PREVALENCE

Among cohort survivors at 43 years, 219 (7\% of the weighted sample) were disabled in at least one area of disability concerned with physical movement and a further $98(3 \%)$ reported difficulties, although they were not assessed as disabled according to OPCS criteria. Six of the 219 physically disabled people and nine others were living in communal establishments. For those living in private households table 1 shows the prevalence of each of the disabilities for men and women separately, and compares them with national prevalences derived from comparable groups in the OPCS data set. Women were more likely to be disabled than men in all four areas of disability but this only reached significance for locomotor activities.

The OPCS data show a substantial increase in the prevalence of most types of disability between the ages of 40-44 years and 45-49 years. With one or two exceptions the prevalence figures for each severe disability derived from the national survey were similar to those 
Table 2 Number of conditions treated in outpatients and number of hospital admissions* (36-43y) according to physical disability and difficulties at 43 years

\begin{tabular}{|c|c|c|c|}
\hline & $\begin{array}{l}\text { Physical } \\
\text { disability } \\
(\%)\end{array}$ & $\begin{array}{l}\text { Physical } \\
\text { difficulty } \\
(\%)\end{array}$ & $\begin{array}{l}\text { No } \\
\text { problem } \\
(\%)\end{array}$ \\
\hline $\begin{array}{l}\text { No of conditions tr } \\
3-4 \\
1-2 \\
\text { None } \\
\text { Total }(=100 \%) \\
\text { p }<0.001\end{array}$ & $\begin{array}{c}\text { (males and } \\
13 \\
65 \\
22 \\
(219)\end{array}$ & $\begin{array}{c}17 \\
55 \\
28 \\
(98)\end{array}$ & $\begin{array}{r}6 \\
50 \\
44 \\
(2918)\end{array}$ \\
\hline $\begin{array}{l}\text { No hospital admiss } \\
\text { Males } \\
\geqslant 3 \\
2 \\
1 \\
\text { None } \\
\text { Total }(=100 \%) \\
\text { Unknown } \\
\text { p }<0.001\end{array}$ & $\begin{array}{c}14 \\
7 \\
21 \\
57 \\
(94) \\
-\end{array}$ & $\begin{array}{c}6 \\
8 \\
21 \\
65 \\
(48) \\
-\end{array}$ & $\begin{array}{r}2 \\
3 \\
15 \\
80 \\
(1470) \\
(8)\end{array}$ \\
\hline $\begin{array}{l}\text { Females } \\
\geqslant 3 \\
2 \\
1 \\
\text { None } \\
\text { Total }(=100 \%) \\
\text { Unknown } \\
\text { p }<0.001\end{array}$ & $\begin{array}{r}9 \\
16 \\
24 \\
51 \\
(124) \\
(1)\end{array}$ & $\begin{array}{c}8 \\
8 \\
50 \\
34 \\
(50) \\
-\end{array}$ & $\begin{array}{r}4 \\
7 \\
20 \\
69 \\
(1436) \\
(4)\end{array}$ \\
\hline
\end{tabular}

* Excluding childbirth.

Table 3 Relative risk of disability at 43 years according to the experience of a serious illness before the age of 25 years

\begin{tabular}{lcc}
\hline Serious illness (0-24y) & No & $\begin{array}{l}\text { Relative risk of } \\
\text { disability at } \\
\text { 43 years }\end{array}$ \\
\hline None & 2214 & $1 \cdot 0$ \\
"Disabling" illnesses:* & 201 & $3 \cdot 4$ \\
Polio & 50 (20) & $(5 \cdot 3)$ \\
Mentral nervous system & $(48)$ & $(3 \cdot 5)$ \\
Circulatory disease & $(25)$ & $(7 \cdot 7)$ \\
Musculoskeletal & $(40)$ & $(4 \cdot 2)$ \\
Congenital & $(53)$ & $(4 \cdot 0)$ \\
Accidents & $(55)$ & $(5 \cdot 0)$ \\
Other serious illness only & $(270)$ & $(2 \cdot 5)$ \\
\hline
\end{tabular}

* Ten survey members included in more than one condition.

derived from the OPCS survey. However the prevalence of each mild disability was substantially greater in the NSHD.

Disabilities with locomotor activities were the most common kind among men and women (combining those with severe or mild disabilities). All other disabilities exhibited a similar prevalence. Among members of the NSHD there was also a higher prevalence of reported difficulties with locomotor activities, followed by difficulties holding, gripping, and turning, then difficulties using arms to reach and stretch for things.

Just under two fifths (39\%) of physically disabled people had more than one disability and just under one fifth $(18 \%)$ had three or four.

\section{DISABILITY AND HOSPITAL CARE}

Those study members with a physical disability or difficulty had more contact with hospital services than the rest of the cohort. They were significantly more likely to have attended hospital as outpatients in the past seven years, and to have consulted about three or more health problems. They also had significantly more hospital admissions (table 2). Those with physical disabilities were the most likely to have had two or more hospital admissions, whereas those with physical difficulties were most likely to have had outpatient consultations about three or more health problems. Over the previous seven years the physically disabled group (who comprise $7 \%$ of the weighted population) had taken up $22 \%$ of bed days. Over their whole lives this group have used $16 \%$ of all bed days which suggests that, at least for some, health care needs have been long term.

\section{SERIOUS ILLNESS IN EARLIER LIFE AND ADULT DISABILITY}

Cohort survivors who had any serious illness before the age of 25 years were over twice as likely to be physically disabled at 43 years than those with no history of childhood serious illness $(11 \%$ compared with $5 \%)$. Conditions or types of conditions associated with a higher than average relative risk of disability at 43 years are shown in table 3. Long hospital admissions associated with congenital conditions were most common in the first few years of life; admissions for conditions of the central nervous system or mental retardation remained important throughout these first 25 years. Polio had its main impact between 6-10 years (cohort members were exposed to the last epidemic in the early 1950s), as did rheumatic fever, a major subgroup of circulatory disease. Hospital admissions or prolonged time off work for circulatory disease, musculoskeletal conditions, and accidents were more common in late adolesecence and early adult life. Although the relative risk of subsequent disability from accidents was not as high as for other conditions, substantial numbers were seriously ill as a result of accidents during adolescence and young adulthood (37 per 1000 at $16-20$ years and 50 per thousand between 21-25 years).

Cohort members were grouped according to their experience of any one of the potentially disabling illnesses listed in table 3 and the age at which it had first occurred. Potentially disabling illnesses before the age of five years were associated with a particularly high risk of subsequent disability among survivors in adult life $(30 \%)$ (see table 4 ). Over a half of all physically disabled adults $(53 \%)$ had experienced a serious illness and $37 \%$ a potentially disabling illness before they were 25 years old compared with less than a third $(30 \%)$ and $14 \%$ of those with no physical disability.

\section{LIFETIME SOCIOECONOMIC FACTORS AND ADULT} DISABILITY

Disabled men and women were significantly less likely to be employed and their current or last occupation was more likely to assign them to the manual classes (table 5). They were significantly less likely to be owner-occupiers and to report a net household income above the median level for this cohort $(£ 15000)$. Disabled men were significantly more likely to have remained single. Disabled women were no less likely to marry but had significantly higher rates of divorce and separation. Those 
Table 4 Physical disability at 43 years according to experience of potentially disabling illnesses and other serious illness before age 25 years

\begin{tabular}{|c|c|c|c|c|}
\hline & $\begin{array}{l}\text { Physical } \\
\text { disability } \\
\%\end{array}$ & $\begin{array}{l}\text { Physical } \\
\text { difficulty } \\
\%\end{array}$ & $\begin{array}{l}\text { No } \\
\text { problem } \\
\%\end{array}$ & $\begin{array}{l}\text { Total } \\
(=100 \%)\end{array}$ \\
\hline $\begin{array}{l}\text { No serious illness } \\
<25 \text { y }\end{array}$ & $5(104)$ & $3(65)$ & $92(2045)$ & $(2214)$ \\
\hline $\begin{array}{l}\text { Disabling illness } \\
0-4 \mathrm{y} \\
5-14 \mathrm{y} \\
15-24 \mathrm{y}\end{array}$ & $\begin{array}{ll}30 & (30) \\
13 & (16) \\
12 & (34)\end{array}$ & $\begin{array}{lr}1 & (1) \\
2 & (3) \\
4 & (12)\end{array}$ & $\begin{array}{lr}69 & (69) \\
85 & (104) \\
84 & (232)\end{array}$ & $\begin{array}{l}(100) \\
(123) \\
(278)\end{array}$ \\
\hline $\begin{array}{l}\text { Other serious illness } \\
<25 \mathrm{y}\end{array}$ & 7 (35) & $3(17)$ & $90 \quad(468)$ & $(520)$ \\
\hline Total & $(219)$ & (98) & (2918) & (3235) \\
\hline
\end{tabular}

experiencing physical difficulties were also socioeconomically disadvantaged, but to a lesser degree.

Socioeconomic disadvantage may be a consequence of disability or, alternatively, earlier disadvantage may have contributed to the risk of disability. Therefore the relationship between disability and socioeconomic factors in earlier life was examined.

Those who had less educated parents, grew up in manual social class homes, or experienced domestic overcrowding when they were young children were significantly more likely to be disabled at 43 years (table 6 ). A stepwise polychotomous logistic regression model (to predict those with a physical disability or a physical difficulty) which took all these factors into account showed that the most important early environmental factor for predicting physical disability at 43 years was father's social class; those from social classes IV and V had a significantly higher risk of physical disability (odds ratio $2 \cdot 1(95 \% \mathrm{CI} 1 \cdot 3,3 \cdot 4)$ ). Once this had been accounted for the other socioeconomic factors in childhood were no longer significantly associated with adult disability. Poor maternal education was the best predictor of physical difficulty (odds ratio $6 \cdot 4$ (95\% CI $2 \cdot 0,21 \cdot 0)$ ).

Those with less education or who were in a lower social class at 26 years were significantly more likely to have physical disabilities or difficulties at 43 years (table 6 ). Further analyses were performed to see whether the relationship between adult disability and childhood socioeconomic environment, as measured by father's social class, could be explained by subsequent educational attainment or adult socioeconomic circumstances, or by the experience of serious illness before 25 years. The analysis compared disabled with non-disabled survey members only, excluding those with physical difficulties because of small numbers. Eighty two per cent of this sample had complete information. Table 7 shows that the odds ratio for each of the independent variables under consideration, adjusted only for the sex of survey members, was slightly lower in the restricted as compared with the total sample (comparing columns 1 and 2). The odds ratio for educational qualifications was most affected, being reduced from 2.2 to 1.8 for those with no qualifications compared with their better educated peers, and indicated that those with no qualifications for whom there was missing information experienced a particular high risk of disability.

The first model showed that father's social class was still significantly related to adult disability even after adjusting for the strong effect of early serious illness, although the odds ratio was slightly reduced. The second model showed that taking account of educational qualifications reduced this odds ratio still further. The last model which took account of social class at 26 years reduced the effect of both father's class and educational qualifications on adult disability to insignificance. The analysis suggests that the association between the early socioeconomic environment and adult disability is primarily accounted for by later adult socioeconomic circumstances. The socioeconomic environment only slightly modifies the relationship between serious illness and adult disability.

The last question asked whether the relative drop in standard of living resulting from disability was cushioned for those who had attained a higher standard of living by early adult life. Table 8 shows the percentages of disabled and non-disabled cohort members employed, who were owner occupiers, or whose household income was above the median level at 43 years, according to social class at 26 years, and illness history. The data are standardised for sex. For the purpose of this analysis those from the non-manual classes were grouped together and those with a history of a potentially disabling illness before 25 years were distinguished from the rest of the cohort, but numbers in some groups are still somewhat small. Comparing disabled and non-disabled people at 43 years with no previous history of illness (columns 1 and 2), disability for those from the manual classes was associated with relatively more disadvantages in income and employment (column 3). There was no significant housing disadvantage. Columns 4 and 5 compared disabled and non-disabled people who had a history of "disabling" illness in early life. Disadvantage increased with falling social class, not only in employment and income but also in housing tenure. Compared with the groups with no history of disabling illness, relative disadvantage was greater in all three areas, particularly in income (column 6).

\section{Discussion}

The prevalence of severe disability in physical movement at 43 years in the NSHD (19 per 1000 for men and 34 per 1000 for women) was similar to that found in the OPCS survey (1622 per 1000 for men and 26-31 per 1000 for women at 40-49 years) but the prevalence of mild disability was considerably higher, probably because of a number of differences in the design of the two studies, particularly at the screening stage. The OPCS study only interviewed people who had been identified as having a disability from the postal questionnaire sent to households. It was possible that minor disabilities of others in the household might be under-reported on the postal ques- 
Table 5 Socioeconomic characteristics at 43 years according to physical disability at 43 years

\begin{tabular}{|c|c|c|c|c|c|c|}
\hline & \multicolumn{3}{|l|}{ Men } & \multicolumn{3}{|l|}{ Women } \\
\hline & $\begin{array}{l}\text { Physical } \\
\text { disability } \\
\%\end{array}$ & $\begin{array}{l}\text { Physical } \\
\text { difficulty } \\
\%\end{array}$ & $\begin{array}{l}\text { No } \\
\text { problem } \\
\%\end{array}$ & $\begin{array}{l}\text { Physical } \\
\text { disability } \\
\%\end{array}$ & $\begin{array}{l}\text { Physical } \\
\text { difficulty } \\
\%\end{array}$ & $\begin{array}{l}\text { No } \\
\text { problem } \\
\%\end{array}$ \\
\hline $\begin{array}{l}\text { Employment status: } \\
\text { Employed } \\
\text { Looking for work } \\
\text { Not looking for work } \\
\text { Not employed, status unknown } \\
\text { Total }(=100 \%)\end{array}$ & $\begin{array}{r}70 \\
9 \\
20 \\
1 \\
(94)\end{array}$ & $\begin{array}{l}85 \\
6 \\
8 \\
- \\
(48) \\
p<0 \cdot 001\end{array}$ & $\begin{array}{r}96 \\
2 \\
2 \\
1 \\
(1478)\end{array}$ & $\begin{array}{c}62 \\
11 \\
24 \\
3 \\
(125)\end{array}$ & $\begin{array}{l}76 \\
6 \\
16 \\
2 \\
(50) \\
\mathrm{p}<0.001\end{array}$ & $\begin{array}{c}83 \\
3 \\
13 \\
2 \\
(14440)\end{array}$ \\
\hline $\begin{array}{l}\text { Social class of current or last } \\
\text { occupation: } \\
\text { I + II } \\
\text { IIINM } \\
\text { IIIM } \\
\text { IV \& V } \\
\text { Total }(=100 \%)\end{array}$ & $\begin{array}{c}40 \\
5 \\
41 \\
14 \\
(78)\end{array}$ & $\begin{array}{l}34 \\
9 \\
48 \\
9 \\
(44) \\
\mathrm{p}<0.01\end{array}$ & $\begin{array}{r}55 \\
9 \\
27 \\
10 \\
(1449)\end{array}$ & $\begin{array}{r}32 \\
32 \\
6 \\
31 \\
(108)\end{array}$ & $\begin{array}{l}28 \\
33 \\
15 \\
25 \\
(40) \\
\mathrm{p}<0.05\end{array}$ & $\begin{array}{r}37 \\
38 \\
7 \\
19 \\
(1310)\end{array}$ \\
\hline $\begin{array}{l}\text { Housing tenure: } \\
\text { Owns it or buying it } \\
\text { Council } \\
\text { Private landlord } \\
\text { Housing association } \\
\text { Other } \\
\text { Total }(=100 \%)\end{array}$ & $\begin{array}{r}68 \\
24 \\
1 \\
1 \\
7 \\
(93)\end{array}$ & $\begin{array}{r}77 \\
10 \\
2 \\
2 \\
8 \\
(48) \\
\mathrm{p}<0.001\end{array}$ & $\begin{array}{r}84 \\
7 \\
4 \\
0 \\
6 \\
(1476)\end{array}$ & $\begin{array}{r}62 \\
22 \\
8 \\
2 \\
6 \\
(126)\end{array}$ & $\begin{array}{l}82 \\
10 \\
2 \\
2 \\
4 \\
(50) \\
\mathrm{p}<0.001\end{array}$ & $\begin{array}{r}85 \\
9 \\
3 \\
0 \\
4 \\
(1438)\end{array}$ \\
\hline $\begin{array}{l}\text { Household net income }(\mathcal{f}) \text { per annum: } \\
\geqslant 15000 \\
\geqslant 12000 \\
\geqslant 10000 \\
\geqslant 8000 \\
\geqslant 6000 \\
<6000 \\
\text { Total }(=100 \%)\end{array}$ & $\begin{array}{l}22 \\
21 \\
13 \\
11 \\
12 \\
22 \\
(86)\end{array}$ & $\begin{array}{l}38 \\
4 \\
16 \\
20 \\
11 \\
11 \\
(45) \\
\mathrm{p}<0.001\end{array}$ & $\begin{array}{r}54 \\
16 \\
12 \\
7 \\
6 \\
5 \\
(1426)\end{array}$ & $\begin{array}{r}33 \\
18 \\
9 \\
9 \\
11 \\
20 \\
(120)\end{array}$ & $\begin{array}{l}42 \\
18 \\
13 \\
9 \\
7 \\
11 \\
(45) \\
\mathrm{p}<0.05\end{array}$ & $\begin{array}{c}49 \\
16 \\
10 \\
8 \\
7 \\
10 \\
(1354)\end{array}$ \\
\hline $\begin{array}{l}\text { Marital status: } \\
\text { Single, never married } \\
\text { Married } \\
\text { Divorced separated } \\
\text { Widowed } \\
\text { Total }(=100 \%)\end{array}$ & $\begin{array}{r}16 \\
76 \\
9 \\
- \\
(94)\end{array}$ & $\begin{array}{l}19 \\
60 \\
19 \\
2 \\
(48) \\
\mathrm{p}<0.001\end{array}$ & $\begin{array}{c}7 \\
82 \\
10 \\
1 \\
(1478)\end{array}$ & $\begin{array}{c}6 \\
73 \\
18 \\
2 \\
(125)\end{array}$ & $\begin{array}{r}4 \\
90 \\
6 \\
- \\
(50) \\
\text { NS }\end{array}$ & $\begin{array}{r}5 \\
80 \\
14 \\
2 \\
(1440)\end{array}$ \\
\hline
\end{tabular}

Table 6 Physical disability at 43 years according to socioeconomic factors in childhood and young adulthood

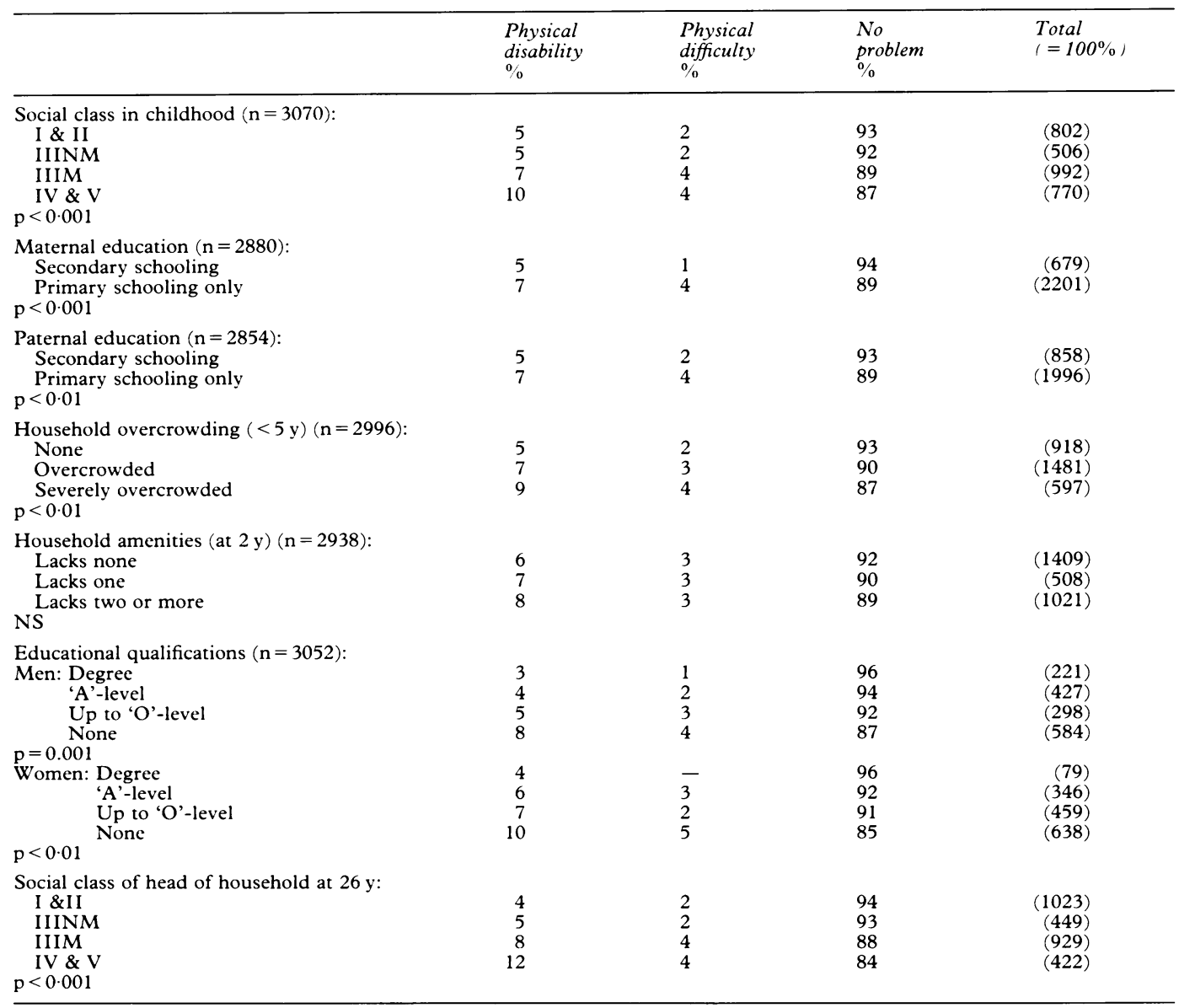


Table 7 Predicting disability at 43 years from history of serious illness and lifetime socioeconomic factors. Odds ratios (95\% confidence intervals)

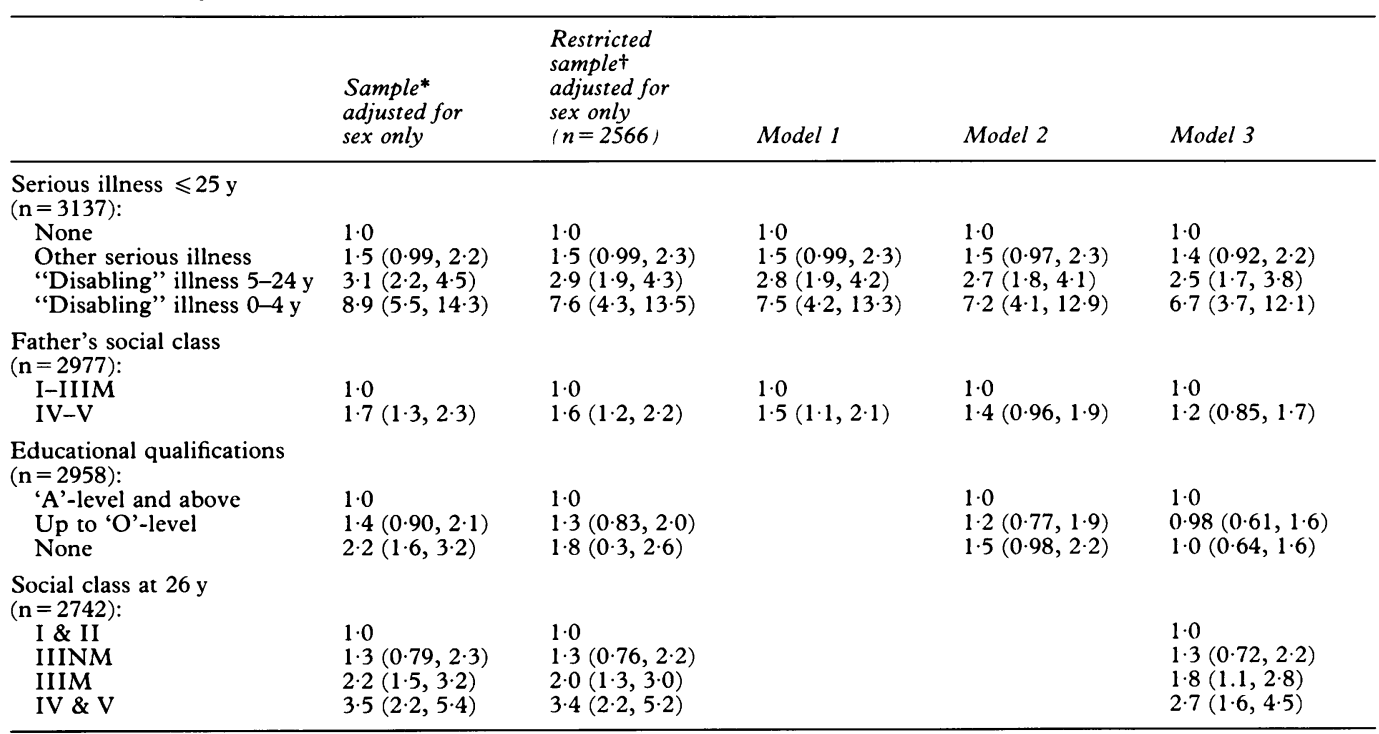

* Excludes those with difficulties only; $\dagger$ with complete information.

Table 8 Percentage in paid employment, owner occupiers and with above average income at 43 years according to social class at 26 years, "disabling" illness up to 25 years, and disability at 43 years (columns 1, 2, 4 and 5 ). Chance of a disabled person having these socioeconomic characteristics at 43 years relative to a non-disabled person with similar socioeconomic and illness histories (columns 3 and 6 )

\begin{tabular}{|c|c|c|c|c|c|c|}
\hline \multirow[b]{2}{*}{$\begin{array}{l}\text { Social class } \\
\text { at } 26 y\end{array}$} & \multicolumn{2}{|c|}{$\begin{array}{l}\text { No “disabling" illness } \\
(0-24 y)\end{array}$} & \multirow[b]{2}{*}{$\begin{array}{l}\text { Ratio of disabled } \\
\text { (col } 1 \text { ) to non-disabled } \\
\text { (col } 2) \\
\text { (3) }\end{array}$} & \multicolumn{2}{|c|}{$\begin{array}{l}\text { "Disabling" illness } \\
(0-24 y)\end{array}$} & \multirow[b]{2}{*}{$\begin{array}{l}\text { Ratio of disabled } \\
\text { (col 4) to non-disabled } \\
\text { (col 5) } \\
(6)\end{array}$} \\
\hline & $\begin{array}{l}\text { Disabled } \\
\text { at } 43 y \\
\text { (1) }\end{array}$ & $\begin{array}{l}\text { Not disabled } \\
\text { at } 43 y \\
\text { (2) }\end{array}$ & & $\begin{array}{l}\text { Disabled } \\
\text { at } 43 y \\
\text { (4) }\end{array}$ & $\begin{array}{l}\text { Not disabled } \\
\text { at } 43 y \\
\text { (5) }\end{array}$ & \\
\hline $\begin{array}{l}\% \text { in a job at } \\
\text { I-IIINM } \\
\text { IIIM } \\
\text { IV \& V }\end{array}$ & $\begin{array}{l}75(46) \\
71(46) \\
68(30)\end{array}$ & $\begin{array}{ll}91 & (1244) \\
88 & (683) \\
91 & (280)\end{array}$ & $\begin{array}{l}0 \cdot 82 \\
0 \cdot 81 \\
0 \cdot 74\end{array}$ & $\begin{array}{l}68(16) \\
62(25) \\
37(20)\end{array}$ & $\begin{array}{l}89(139) \\
88(137) \\
85(76)\end{array}$ & $\begin{array}{l}0 \cdot 76 \\
0 \cdot 70 \\
0 \cdot 44\end{array}$ \\
\hline $\begin{array}{l}\% \text { owner occ } \\
\text { I-IIINM } \\
\text { IIIM } \\
\text { IV \& V }\end{array}$ & $\begin{array}{l}43 y: \\
86(46) \\
77(45) \\
68(30)\end{array}$ & $\begin{array}{lr}91 & (1244) \\
80 & (681) \\
71 & (280)\end{array}$ & $\begin{array}{l}0.95 \\
0.96 \\
0.96\end{array}$ & $\begin{array}{l}87(16) \\
55(25) \\
34(20)\end{array}$ & $\begin{array}{l}89(139) \\
80(137) \\
57(76)\end{array}$ & $\begin{array}{l}0 \cdot 98 \\
0 \cdot 69 \\
0 \cdot 60\end{array}$ \\
\hline $\begin{array}{l}\% \text { top half of } \\
\text { I-IIINM } \\
\text { IIIM } \\
\text { IV \& V }\end{array}$ & $\begin{array}{l}\text { at } 43 \mathrm{y}: \\
60(47) \\
23(46) \\
22(27)\end{array}$ & $\begin{array}{ll}66 & (1195) \\
36 & (654) \\
34 & (265)\end{array}$ & $\begin{array}{l}0.91 \\
0.64 \\
0.65\end{array}$ & $\begin{array}{r}35(14) \\
12(24) \\
6(18)\end{array}$ & $\begin{array}{l}65(134) \\
34(133) \\
29(68)\end{array}$ & $\begin{array}{l}0 \cdot 54 \\
0 \cdot 35 \\
0 \cdot 21\end{array}$ \\
\hline
\end{tabular}

tionnaire at the screening stage; investigation of the response to another household based postal questionnaire on disability carried out in Calderdale ${ }^{20}$ suggested that such underreporting occurs. In comparison, the NSHD is a general population sample and the participants were not chosen for inclusion in the survey because of reported difficulties in daily activities. The screening stage, a self completed checklist, took place in the presence of the interviewer who had instructions to include rather than exclude anybody at the screening stage if there was any uncertainty. Disabilities were reported by the individuals themselves so there was no possibility of a proxy effect.

The screening questionnaire used by OPCS made explicit the survey's association with the DHSS and its aim of helping to develop policies for services and benefits for disabled people. This may have discouraged some from revealing their disabilities if they did not think they needed services or benefits, or it they did not perceive themselves as disabled despite mild restrictions in their daily lives. In contrast, in the NSHD the questions about disabilities were part of an interview which asked about all aspects of health and life circumstances and there was no particular focus on disability and no suggestion that the survey was carried out to help develop policies for disabled people. Members of the cohort have been visited throughout their lives and have shown a long term commitment to participate in the study. All these factors would have tended to encourage the reporting of all difficulties in the specified physical activities.

The OPCS survey demonstrated that disabled people have a higher consumption of health care. ${ }^{6}$ This study confirms and extends these findings by demonstrating that lifetime as well as more recent experience of hospital care was significantly greater in the disabled group. Recent outpatient consultations were also higher. Those with physical difficulties were more likely to consult about several conditions and suggests that members of this group suffer from general ill health.

More than half of all physically disabled adults at 43 years had experienced a serious illness in the first 25 years of life compared with less than a third of those who were not disabled. Our data cannot confirm whether there is any aetiological connection between a 
serious illness earlier in life and the risk of physical disability at 43 years; even on an individual basis the clinician may find this hard to assess. But it does suggest that in this post war cohort those who survived a serious illness in early life have been more susceptible to health problems in adult life. The high relative risk of disability in adult life for those who were seriously ill in childhood from polio is particularly interesting as the long term effects of polio on the musculoskeletal system are becoming more widely recognised. ${ }^{21}$

Our findings show an association between poor childhood socioeconomic circumstances and risk of disability in adult life. Further analysis indicated that this was an indirect association due to the greater risk of low adult socioeconomic status for those brought up in poor families. Poor circumstances in adult life contributed to the risk of disability, and this relationship was maintained even after adjusting for the influence of earlier serious illness. There was no interaction between these two predictors of disability which indicated that the socioeconomic environment had its effect on disability for those with and without prior health problems. These findings are dependent on the extent to which onset of disability before age 26 years (which was unknown) had been taken into account in the measure of serious illness.

The findings from this study showed that disability was related to current socioeconomic circumstances even after taking account of previous circumstances and illness history. Disability had most impact on income and then on employment; housing tenure was less affected. This is understandable as disability could have an immediate effect on earnings by reducing productivity or hours worked, or causing a shift into lower paid work. Giving up employment altogether may not occur unless the disability is long term or worsens. Earlier rather than current economic circumstances may have more influence on current housing tenure. The income and employment consequences of disability were greater for people who had come from the lower social classes. This may be because the level of income depends more on piece work and overtime in manual occupations and is thus more directly related to physical capacity. Manual jobs are more physically demanding and offer less control over the working environment and this may mean that disabled people in these jobs have to give up working at a less severe level of disability.

It is intended to measure disability again in future sweeps of this post war cohort in order to assess the rate of change with age, the extent to which individuals continue to suffer from particular disabilities over several years, and the changes in risk factors for disability and its social and health care consequences as the cohort ages.

\section{Conclusions}

This study has shown that disabilities and difficulties with physical movement are a signi- ficant health problem for the birth cohort born immediately after the second world war, affecting more than one in 10 by age 43 years. The prevalence of mild disability seems to be greater than the prevalence derived from studies of disabled people. Childhood ill health was found to be a strong predictor of adult disability in this cohort. The implication for health care is that good transitional arrangements between paediatric and adult health care services are needed, in order to pick up signs of disability as soon as possible and offer early preventive care. The need for better coordination between child and adult health services was made forcefully by the Court report on child health services in $1976 . .^{22}$ Disability in early middle life has significant social and health care consequences. Social disadvantage affects the risk of disability and its financial and employment consequences.

1 World Health Organisation. International classification of impairments, disabilities and handicaps. Geneva: WHO, 1980.

2 Bebbington AC. The expectation of life without disability in England and Wales. Soc Sci Med 1988;27:321-6.

3 Bebbington AC. The expectation of life without disability in England and Wales: 1976-88. Pop Trends in England

4 Robine JM, Ritchie K. Healthy life expectancy: evaluation of global indicator of change in population health. $B M \mathcal{F}$ 1991;302:457-60.

5 Martin J, Meltzer $\mathrm{H}$, Elliot D. The prevalence of disability among adults. OPCS Surveys of disability in Great Britain. Report 1. OPCS Social Survey Division. London HMSO, 1988.

6 Martin J, White A, Meltzer H. Disabled adults: services, transport and employment. OPCS Surveys of disability in Great Britain. Report 4. OPCS Social Survey Division. London: HMSO, 1989.

7 Harris AI. Handicapped and impaired in Great Britain. OPCS Social Survey Division, London: HMSO, 1971.

8 Kuh D, Lawrence C, Tripp J, Creber G. Work and work alternatives for disabled young people. Disability, handicap and society 1988;3:3-26.

9 Martin J, White A. The financial circumstances of disabled adults living in private households. OPCS surveys of disabadults living in private households. OPCS surveys of disab-
ility in Great Britain. Report 2. OPCS Social Survey ility in Great Britain. Report 2.

10 Verbrugge LM, Gates DM, Ike RW. Risk factors for disability among US adults with arthritis. $f$ Clin Epidemiol 1991;44:167-82.

11 Pinsky JL, Branch LG, Jette AM, Haynes SG, Feinleib M, Cornoni-Huntley JC, Bailey KR. Framingham disability study: relationship of disability to cardiovascular risk factors among persons free of diagnosed cardiovascular disease. Am F Epidemiol 1985;122:644-56.

12 Keil JE, Gazes PC, Sutherland SE, Rust PF, Branch LG Tyroler HA. Predictors of physical disability in elderly blacks and whites of the Charleston Heart Study. $\mathcal{J}$ Clin Epidemiol 1989;42:521-9.

13 Lammi UK, Kivela S-L, Nissinen A, Punsar S, Puska P, Karvonen $M$. Predictors of disability in elderly Finnish men - a longitudinal study. f Clin Epidemiol 1989; men - a lis 1 - 25 .

14 Wadsworth MEJ, Mann SL, Rodgers B, Kuh DJL, Hilder WS, Yusuf EJ. Loss and representativeness in a 43 year follow-up of a national birth cohort. $\mathcal{f}$ Epidemiol Community Health 1992;46:300.

15 Wadsworth MEJ. Serious illness in childhood and its association with later life achievements. In: RG Wilkinson ed. Class and health. London: Tavistock Publications, 1986.

16 World Health Organisation. International classification of diseases. 9th rev. Geneva: WHO, 1977.

17 Office of Population Censuses and Surveys. Classification of occupations 1970. London: HMSO, 1970.

18 Department of Education and Science Burnham Further Education Committee grading courses 1972. London: HMSO, 1972.

19 Dixon WJ, Brown MB, Engelman L, Jennrich RI. BMDP Statistical Software Manual. Vol 2. Berkley: University of California Press, 1990.

20 Tennant A, Badley EM, Sullivan M. Investigating the proxy effect and the saliency principle in household based postal questionnaires. $\mathcal{f}$ Epidemiol Community Health 1991;45:312-16.

21 Ashton JW. Post-polio syndrome. An emerging threat to polio survivors. Postgrad Med 1992;92:249-56.

22 Committee on Child Health Services. Fit for the future. Vol 1. Cmnd 6684. London: HMSO, 1976. (Court report). 